\title{
Removal of Nonmyrmecochorous Seeds by Ants: Role of Ants in Cattle Grasslands
}

\author{
Selene Escobar-Ramírez, Sebastián Duque, Natalia Henao, \\ Alejandra Hurtado-Giraldo, and Inge Armbrecht \\ Department of Biology, University of Valle, A.A., 25360 Cali, Colombia \\ Correspondence should be addressed to Selene Escobar-Ramírez, escobar.selene@gmail.com
}

Received 2 June 2011; Accepted 27 July 2011

Academic Editor: Jacques H. C. Delabie

Copyright (C) 2012 Selene Escobar-Ramírez et al. This is an open access article distributed under the Creative Commons Attribution License, which permits unrestricted use, distribution, and reproduction in any medium, provided the original work is properly cited.

\begin{abstract}
Livestock production models prevailing in Colombian Andes are simplified treeless pastures for extensive ranching, with the consequent reduction of environmental services, such as seed dispersal, due to lack of primary dispersers, scarcity of adequate sites for seedling establishment and competition with grasses. This study evaluated if, in these harsh environments, ants can promote the colonization of arboreal species through directed dispersion of seeds towards the nests. Ten seeds of each species were offered to ants in six grazing pastures. Ants removed $25 \%$ of the seeds (1827) in 48 hours. Preference for arillated and small-to-medium sized seeds, such as Pithecellobium dulce, and Guazuma ulmifolia, was observed. Cyphomyrmex major, Ectatomma ruidum, Solenopsis geminata and Atta cephalotes were the key ant species in seed removal. It was concluded that functional ant groups present in the pastures could contribute to secondary dispersion of seeds with potential for restoration.
\end{abstract}

\section{Introduction}

In Latin America, cattle raising is perhaps the productive activity that most contributes to simplification of the landscape. For instance, in Colombia, cattle raising is predominant in more than $80 \%$ of the Andean Region, an area inhabited by $70 \%$ of the population [1]. The concept of functional diversity relates ecosystemic processes to species diversity through patterns of resource use $[2,3]$. Thus, reduction in plant heterogeneity caused by traditional production systems of cattle raising leads to a reduction of both ecosystemic processes and the environmental services they provide [1].

Vegetal regeneration is limited in cattle pastures due to the absence of dispersers, little availability of viable propagules and of adequate sites for germination, and establishment of seedlings $[4,5]$. Also, competition for the few nutrients with introduced grasses under rude environmental conditions reduces establishment options for arboreal species.

Ants could play a role in the recovery of disturbed systems potentiating recolonization of plant species in agro ecosystems by removing seeds towards their nests $[6,7]$. This interaction could affect the local abundance and distribution of myrmecochorus and nonmyrmecochorous species [810]. In spite of the growing information on the interaction between ants and seeds in neotropical forests [11-14], few studies document the process in neotropical agroecosystems (but see [15-17]). Thus, the role of ants as dispersers of nonmyrmecochorus seeds in pastures is unknown.

The use of diaspores by opportunistic ground dwelling ants can affect the biology of seeds and seedlings of plant species dispersed mainly by vertebrates [18]. The ants can rearrange the rain of seeds produced by primary disperser, facilitate their germination $[19,20]$, and promote the establishment of their seedlings [21,22]. The seeds introduced into the nests are not found by predators and remain protected from adverse environmental events, such as burning in ecosystems that experience regular fires [8]. Although nonmyrmecochorous plants produce seeds without specialized adaptations for dispersal by ants, the presence of arils or nutritious tissues is not indispensable for transport to occur $[16,23]$.

Events of seed removal by ants are influenced by both morphological factors of the seeds and morphological and behavioral traits of the ants. The presence of a nutritious 
tissue or aril attracts the attention of ants thereby increasing probability of an encounter [24]. Once the ant locates the seed, removal will depend on its weight and the carrying capacity of the ant $[25,26]$. In general, large ants possess a greater carrying capacity in their jaws and can remove seeds greater distances [27, 28]. Nevertheless, small ants usually massively recruit workers towards the seeds and then displace them towards the nests $[17,29]$.

Characterization of ant-seed interaction under pasture conditions is a first step towards understanding the potential of ants as functional agents in the ecological recovery of cattle pasture by the dispersal of seeds of plants useful for ecological restoration and seeds of interest to peasant farmers (i.e., forage). This study predicted that ants associated with grasslands act as functional agents by removing nonmyrmecochorous seeds from trees that are useful for ecological rehabilitation. Specifically, the following questions were addressed. Do ants in open pastures actively remove seeds of nonmyrmecochorous plant species with a potential for the ecological recovery of pastures? Do these ants exhibit a preference for a certain kind of seed? Which ant species are most frequently involved in removal events? In addition, the implications of the observed interactions were discussed.

\section{Materials and Methods}

2.1. Study Site. Fieldwork was carried out between September and October 2009 in six cattle pastures located in the flat inter-Andean Cauca River Valley area in the Departments of Valle and Cauca (Southwestern Colombia) covering an area of approximately $627 \mathrm{~km}^{2}$. The farms and geographic locations are as follows: I. Department of Cauca, (1) Limonar $\left(03^{\circ} 08^{\prime} 10.1^{\prime \prime} \mathrm{N} ; 76^{\circ} 27^{\prime} 42.2^{\prime \prime} \mathrm{W}\right)$, (2) La Josefina $\left(3^{\circ} 5^{\prime} 17.3^{\prime \prime} \mathrm{N} ; 76^{\circ} 28^{\prime} 18.5^{\prime \prime} \mathrm{W}\right)$, (3) Cachimbalito $3^{\circ} 9^{\prime} 1.00^{\prime \prime} \mathrm{N}$; $\left.76^{\circ} 27^{\prime} 46.00^{\prime \prime} \mathrm{W}\right)$; II. Department of Valle del Cauca, (4) Sachamate $\left(3^{\circ} 16^{\prime} 27.49^{\prime \prime} \mathrm{N} ; 76^{\circ} 33^{\prime} 28.00^{\prime \prime} \mathrm{W}\right)$, (5) Lituania $\left(3^{\circ} 20^{\prime} 48.5^{\prime \prime} \mathrm{N} ; 76^{\circ} 30^{\prime} 30.6^{\prime \prime} \mathrm{W}\right),(6)$ Marañón $\left(3^{\circ} 20^{\prime} 48.30^{\prime \prime} \mathrm{N}\right.$; $\left.76^{\circ} 31^{\prime} 23.91^{\prime \prime} \mathrm{W}\right)$. Over a century ago, dry tropical forest dominated the region [30], but at present only $2.7 \%$ of the original forest remains, the remainder having been replaced with great expanses of sugarcane fields and cattle farms [31]. Average annual temperature is $24^{\circ} \mathrm{C}$, and average annual precipitation fluctuates between 1000-15000 mm [30] with peaks in March-May and October-December [32]. During the sampling, the pastures averaged temperatures of 29.4 $\pm 3.7^{\circ} \mathrm{C}$ and an average relative humidity of $63.4 \pm 11 \%$. Each pasture was open, with an average extension of at least two hectares and an arboreal density inferior to $4 \%$. Dominant vegetation consisted of Cynodon plectostachyus, an introduced grass, as well as other African grasses like Brachiaria decumbens, accompanied by weeds from Malvaceae and Asteraceae families. Inside the pasture, some isolated trees of Guazuma ulmifolia, Pithecellobium dulce, and Albizia saman are allowed by the farmers to provide shade to the cattle and supplement its feed. During the experiments, the cattle were removed from the lot.

Orthodox seeds from five arboreal species commonly found in pastures were used: (1) Guazuma ulmifolia Lam. (Sterculiaceae), seeds with hydrophilic mucilage; (2)
Pithecellobium dulce (Roxb.) Benth. (Leguminosae-Mimosoideae), arillated seeds; (3) Senna spectabilis (DC.) H. S. Irwin \& Barneby (Leguminosae-Caesalpinioideae), nonarillated seeds; (4) Leucaena leucocephala (Lam.) de Wit. (Leguminosae-Mimosoideae), seeds without arils, and (5) Albizia saman (Jacq.) Merr. (Leguminosae-Mimosoideae) which seeds are usually impregnated with a sweet, oily substance (seeds of $A$. saman used here lack of this substances as they become from a certified seed company provider). Seeds used have a potential for the restoration of livestock systems and with exception of $L$. leucocephala represent part of the native vegetation of open areas. These trees also serve as forage for cattle as they consume the foliage and/or fruit, provide shade for the cattle, protect the ground from erosion, and offer new habitats for other animals. Seeds of Passiflora ligularis Juss. (Passifloraceae) was employed as a positive control. Its seeds are intermediate in size, and they are neither orthodox nor recalcitrant [33]. Their removal by ants was verified in previous studies in disturbed habitats such as pastures $[16,34]$ and mining areas undergoing rehabilitation [17].

In order to sample the ant community, a lineal transect of $190 \mathrm{~m}$ with 10 sampling units (SUs), separated $20 \mathrm{~m}$ from one another, was established. Each SU consisted of a circle of white paper $12 \mathrm{~cm}$ in diameter with $5 \mathrm{~g}$ of tuna in oil and approximately $0.5 \mathrm{~mL}$ of honey. These were left on the ground for a period of 2 hours. The ants attracted to baits were collected in alcohol (96\%), identified to morphospecies, and conserved in a reference collection deposited in the Entomology Museum of the Universidad del Valle (Cali, Colombia). The functional guilds (sensu Silvestre et al. [35]) to which the collected ants belonged were identified. Hill N1 and N2 Number Series were calculated [36] for establishing the number of abundant and very abundant species, respectively.

Three transects were simultaneously established in each pasture: a transect that allows ants access to the seeds ("Ant Transect"), a transect that excluded the ants ("Exclusion transect"), and a transect with seeds of P. ligularis to which the ants had access ( $P$. ligularis Transect). Each transect consisted of 20 seed depots located 10 meters apart. A depot consisted of a disk of white paper $12 \mathrm{~cm}$ in diameter containing 10 seeds of each of the five species used in the study and covered by netting to exclude vertebrate activity. In the excluded transect, each depot was isolated by encircling it within a PVC arum, $12 \mathrm{~cm}$ in diameter and $6 \mathrm{~cm}$ high, the upper edge impregnated with an adhesive substance (tangle foot). In order to guarantee independence, transects were 5 to $10 \mathrm{~m}$ apart. Seeds were served at 0700 hours, and the number of seeds of each species removed at 2, 4, 8, 24, and 48 hours after serving the depots was registered. A seed removed out of the depot was considered a removal event. The species of ants observed removing seeds were identified. A total of 2400 seeds of each species in the study and $1200 P$. ligularis seeds were offered, for a total of 13200 seeds offered during the entire experiment. The response variable was the proportion of seeds removed per depot $\left(P_{i}\right)$. For purposes of analysis, the response variable was transformed by the function arcsine $\sqrt{ } P_{i}$. To evaluate ant preference for seeds, 
a two-factor analysis of variance under a mixed effect model [37] of the following type was carried out:

$$
\begin{aligned}
P_{i j}(\text { Removal proportion })= & \mu+\alpha_{i}(\text { plant species }) \\
& +\beta_{j}(\text { cattle pasture })+E_{i j}(\text { error }),
\end{aligned}
$$

where types of seeds represent fixed effects and the pastures the random effects. To establish whether the removal events were associated with removal by ants and not other factors, the proportion of seeds removed in Ant Transect and Exclusion Transect were compared. Removal dynamics over time was described for all species. For the two most preferred species, $0,25,50,75$, and $100 \%$ percentiles were calculated to estimate removal percentages at 2, 4, 8, 24, and 48 hours after offer, respectively.

\section{Results}

A total of 21 morphospecies distributed in 13 genera and 5 subfamilies for a total of 3471 individuals were collected (Table 1). The most representative genera were Pheidole (6 morphospecies and 176 individuals) and Solenopsis (four morphospecies and 1315 individuals) (both Myrmicinae). Crematogaster abstinens (Myrmicinae), present in six pastures, was the most abundant species with 1774 individuals. The number of ant species found in baits in each pasture fluctuated between 6 and 11. Diversity $\left(H^{\prime}\right.$ index between 0.52 and 1.75$)$ and equitability $\left(J^{\prime}\right.$ index between 0.29 and 0.51 ) were also consistently low in all the lots, there being from two to three very abundant species in each pasture (averages values of $\mathrm{N} 1$ and $\mathrm{N} 2$ estimated as 3 and 2 species, respectively).

The composition of ants attracted to tuna baits was characterized by a predominance of generalist species native to open and degraded habitats. In spite of low richness and equitability, the genera collected represent 8 of the 15 functional guilds described by Silvestre et al. [35] for the Cerrado, Brazil.

Based on ant species composition, the lots do not form agglomerations corresponding to their spatial proximity. In spite of the spacial scale, important variations in ant composition were found (Table 1). But, on a functional level, the pastures contained the same functional guilds.

Ants removed 25\% of the seeds, for a total of 1827 seeds removed in 48 hours period. In general, ant preference for seeds with attractive external tissues was found $(F=17.6 ; P$ $<0.01 ; g l=5)$. Of the five species of interest to the cattleman, the most preferred was G. ulmifolia with 56\% removal, followed by $P$. dulce with $25 \%$ removal while removal did not surpass $10 \%$ for the other species (Table 2).

The presence of ants notably favored the removal of $G$ ulmifolia and P. dulce. In the absence of ants (Exclusion Transect), the removal of these species was drastically reduced. Actually, in the case of $P$. dulce, removal was null when the ants were excluded. On the other hand, access of ants to the depots (Ant Transect) did not significantly favor the removal of $S$. spectabilis $\left(F_{1.5}=4.35 ; P=0.09\right)$,

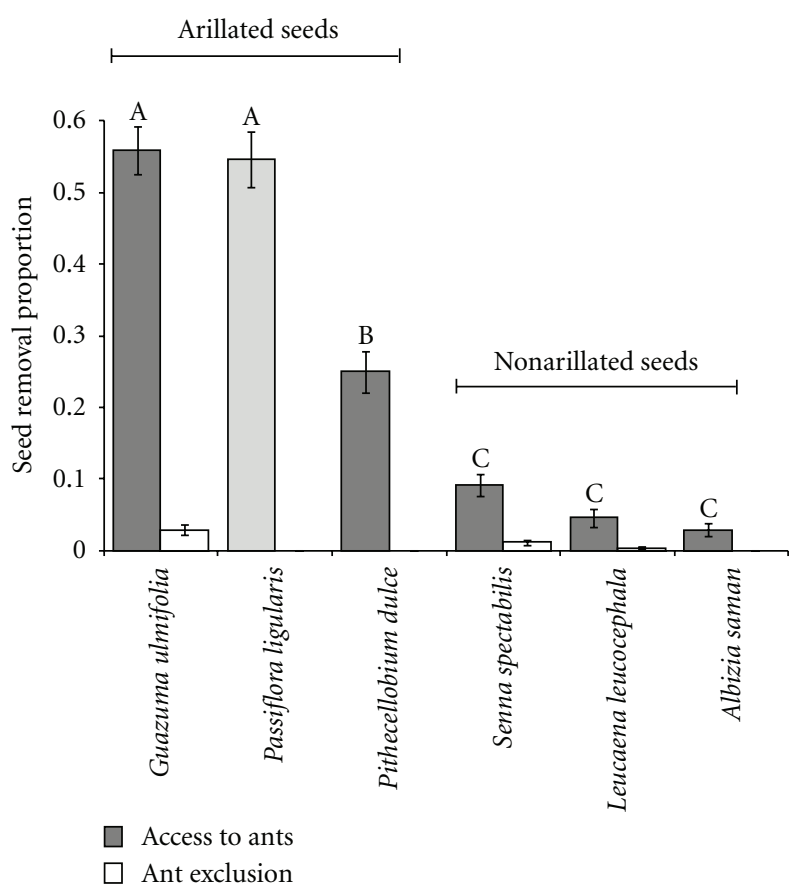

Figure 1: Mean $( \pm$ SE) removal of nonmyrmecochorous seeds by ants in cattle grasslands. Letters above columns show different seed preference groups by ants after a Newman-Kewls test $(\alpha=0,05)$.

L. leucocephala $\left(F_{1.5}=5.17 ; P=0.07\right)$, and $A$. saman $\left(F_{1.5}\right.$ $=4.37 ; P=0.09$ ) (Figure 1). The seeds preferred by the ants were separated into three main groups in the following order of preference: Group A with small G. ulmifolia seeds with mucilage, which were preferred as much as the arillated $P$. ligularis seeds in the positive control (P. ligularis Transect) $(t$ $=0.28 ; P=0.78)$. Group B consisted of arillated but heavier $P$. dulce seeds. Group C was made up of smooth covered, nonarillated S. spectabilis, L. leucocephala, and A. saman seeds (Figure 1).

In general, a greater seed removal rate was observed from 8 to 24 hours after initiating the offer (Figure 2), a pattern maintained in each of the cattle pastures sampled. The removal dynamic overtime of the two most preferred seeds suggests an increase in transporting G. ulmifolia and P. dulce seeds during the night (Table 3).

Very low percentages of removed seeds of G. ulmifolia and $P$. dulce seeds were re-located: only $2 \%$ and $24 \%$, respectively. The majority of the G. ulmifolia and $P$. dulce seeds were removed an average of $20 \mathrm{~cm}$ from the depot, and an important part of the seeds were removed a distance of at least $10 \mathrm{~cm}$. However, the final distance of these seeds could not be established. A Cyphomyrmex major worker transported a G. ulmifolia seed $1.20 \mathrm{~m}$ before entering the nest in the ground while an Ectatomma ruidum worker transported a $P$. ligularis seed $4.6 \mathrm{~m}$ from the depot.

The ant species that most frequently, and in greatest number, approached the tuna baits were, also, those most frequently involved in seed removal events. The ants observed transporting seeds in grasslands belong to three functional groups: (1) a dominant group of small-sized myrmicines 
TABle 1: Composition and total abundance of ant species attracted to tuna and honey baits in each locality. (Sa: Sachamate, LJ: La Josefina, Ca: Cachimbalito, Lit: Lituania, Ma: Marañón, Li: Limonar).

\begin{tabular}{|c|c|c|c|c|c|c|c|}
\hline Morphospecies & $\mathrm{Sa}$ & LJ & $\mathrm{Ca}$ & Lit & $\mathrm{Ma}$ & Lim & Total abund. \\
\hline \multicolumn{8}{|l|}{ Myrmicinae } \\
\hline Atta cephalotes & & & & & & 1 & 1 \\
\hline Cardiocondyla gr. minutior & 7 & & & & & & 7 \\
\hline Crematogaster abstinens & 73 & 644 & 75 & 56 & 822 & 104 & 1774 \\
\hline Cyphomyrmex major & & 4 & 5 & & & 3 & 12 \\
\hline Pheidole ebenina & & 22 & & & & & 22 \\
\hline Pheidole susannae & & 26 & 85 & 7 & 8 & 4 & 130 \\
\hline Pheidole sp1 & 1 & & 1 & & & & 2 \\
\hline Pheidole sp2 & & & & 5 & & & 5 \\
\hline Pheidole sp3 & & & 3 & & & 2 & 5 \\
\hline Pheidole sp5 & & & & & & 12 & 12 \\
\hline Solenopsis geminata & 213 & 206 & 298 & 72 & 160 & 321 & 1270 \\
\hline Solenopsis sp1 & 4 & & & 35 & & 1 & 40 \\
\hline Solenopsis sp2 & 4 & & & & & & 4 \\
\hline Solenopsis sp3 & 1 & & & & & & 1 \\
\hline Wasmannia auropunctata & 27 & 43 & & 10 & & 41 & 121 \\
\hline \multicolumn{8}{|l|}{ Formicinae } \\
\hline Brachymyrmex sp1 & 6 & & & & & & 6 \\
\hline Camponotus sp1 & & & & 4 & & & 4 \\
\hline Nylanderia sp1 & & & & 8 & 3 & & 11 \\
\hline \multicolumn{8}{|l|}{ Ectatomminae } \\
\hline Ectatomma ruidum & & 11 & 6 & 11 & 1 & 9 & 38 \\
\hline \multicolumn{8}{|l|}{ Ponerinae } \\
\hline Hypoponera sp1 & & 1 & & & & & 1 \\
\hline \multicolumn{8}{|l|}{ Pseudomyrmecinae } \\
\hline Pseudomyrmex sp1 & & & 2 & 1 & 1 & 1 & 5 \\
\hline
\end{tabular}

TABLE 2: Mean seed removal of nonmyrmecochorous seeds by ants in cattle grasslands. Standard errors are shown for seed weights.

\begin{tabular}{|c|c|c|c|c|c|c|}
\hline \multirow{2}{*}{ Type of seed } & \multirow{2}{*}{ Species } & \multirow{2}{*}{ Seed weight (g) } & \multicolumn{2}{|c|}{ Ant access } & \multicolumn{2}{|c|}{ Ant exclusion } \\
\hline & & & Seeds removed & Removal percentage & Seeds removed & Removal percentage \\
\hline \multirow{3}{*}{ Arillated } & G. ulmifolia & $0.005 \pm 0.00$ & 672 & $56.0 \%$ & 35 & 2.9 \\
\hline & P. dulce & $0.307 \pm 0.10$ & 300 & $25.0 \%$ & 0 & 0.0 \\
\hline & P. ligularis & $0.16 \pm 0.02$ & 656 & $54.7 \%$ & N/A* & N/A \\
\hline \multirow{4}{*}{ Nonarillated } & S. spectabilis & $0.026 \pm 0.00$ & 109 & $9.1 \%$ & 14 & 1.2 \\
\hline & L. leucocephala & $0.062 \pm 0.01$ & 55 & $4.6 \%$ & 4 & 0.3 \\
\hline & A. saman & $0.233 \pm 0.03$ & 35 & $2.9 \%$ & 0 & 0.0 \\
\hline & Total & & 1827 & $25.4 \%$ & 53 & $4.4 \%$ \\
\hline
\end{tabular}

${ }^{*}$ N/A: Not Applicable. Ant exclosures were not performed in P. ligularis transect.

TAble 3: Percentiles for the total removal percentage of Pithecellobium dulce and Guazuma ulmifolia nonmyrmecochorous seeds in six cattle pastures in Cauca and Valle.

\begin{tabular}{|c|c|c|c|c|}
\hline \multirow{2}{*}{ Percentile } & \multirow{2}{*}{ Observation period } & \multirow{2}{*}{ Hour of the day } & \multicolumn{2}{|c|}{ Percentage of seeds removed } \\
\hline & & & P. dulce & G. ulmifolia \\
\hline $0 \%$ & 2 hours & 0800 hours & 2.17 & 1.08 \\
\hline $25 \%$ & 4 hours & 1200 hours & 2.92 & 1.33 \\
\hline $50 \%$ & 8 hours & 1600 hours & 16.6 & 1.92 \\
\hline $75 \%$ & 24 hours & 0800 hours & 44.8 & 15.7 \\
\hline $100 \%$ & 48 hours & 0800 hours & 56.3 & 25.0 \\
\hline
\end{tabular}




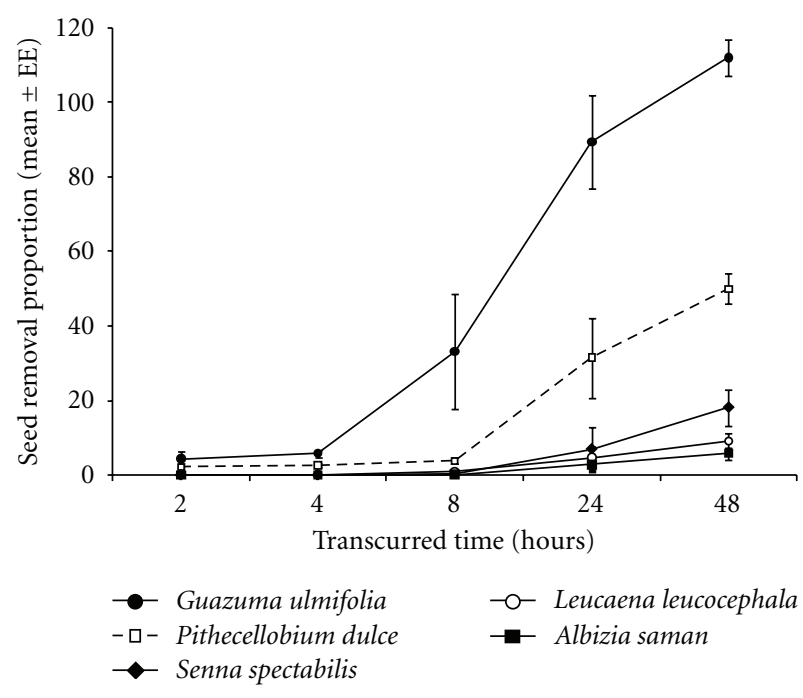

Figure 2: Removal of seeds by ants overtime. Average number of seeds removed from depots $2,4,8,24$, and 48 hours, after initiating offer, are showed $(n=6)$.

with generalist habits (Pheidole spp., Solenopsis geminata, and C. abstinens); (2) two species of attine, a leaf-cutter (Atta cephalotes), and a cryptic fungus grower (Cyphomyrmex major) which were the main seed transporters of $P$. dulce and G. ulmifolia, respectively; (3) a large epigeal ponerinae (E. ruidum), very common and abundant in disturbed lowland habitats (0 to 1500 m.a.s.l.) (Table 4 ).

Removal activity seems to be occurring throughout the day, with great activity of generalist species during the morning hours such as E. ruidum and other small myrmicine, and great activity of attines after 17:00 hours, the activity of $C$. major and A. cephalotes increased.

\section{Discussion}

The ant community associated to cattle pastures in the study area is not very diverse and has a great predominance of only a few species and a relatively predictable composition. The simplification of plant structure in pastures and the surrounding matrix could explain the limited ant diversity [38]. The pattern of diversity found is that expected for the highly fragmented landscape of the biogeographical valley of the Cauca River where pastures and sugar cane fields dominate, and there is only $2 \%$ forest cover immersed in a low-quality matrix $[39,40]$. The results of this study are consistent with Armbrecht and Ulloa-Chacón [41] who, one decade earlier, found that ant diversity reduced drastically in the pasturelands with respect to forest fragments. In the same area of this study, they found only 21 species in the productive systems, using six capture methods. In spite of limited diversity, generalist ants in pastures rapidly located and displaced the seeds offered in the depots. Twenty-four percent of the seeds were removed for a total of 1827 removal events during a 48-hour period in treeless pastures with cattle activity and compact, ecologically degraded soil. These removal values are similar to those found by Escobar et al.
[16] who reported a $26 \%$ total removal in open grasslands and silvopastoral systems in Valle del Cauca and Quindío, while Zelikova and Breed [15] reported 38.3.\% removal in open pastureland in Costa Rica. Although total seed removal did not exceed $40 \%$, each removal event as such is of biological importance because it potentiates a possibly effective dispersion event. This is particularly critical in highly disturbed habitats rarely visited by primary dispersers.

Results in the Excluded Transect and direct observation indicate that ants are important seed dispersers of trees useful in ecological recovery of degraded ecosystems. Ants have morphological adaptations which allow them to carrying seeds. Also, their social behavior promotes seed transport from the foraging point to their nests, where conditions may be more favorable for the germination and growth of seedlings. Tendency towards territoriality and the stability of their colonies in the tropics makes removal by ants a permanent ecological service throughout the year. These aspects allow to consider ants as key functional agents, facilitating the distribution of seeds of interest in pasturelands.

Ant preference for seeds with an attractive, nutritious tissue in G. ulmifolia, P. dulce, and P. ligularis was found. This result coincides with the pattern identified for myrmecochorus and nonmyrmecochorous seeds in multiple habitats worldwide $[14,18]$. The G. ulmifolia species was preferred as much, or more than the P. ligularis (positive control) seeds. However, while in the present study, the ants removed $56 \%$ of the G. ulmifolia seeds, this species was the less preferred in mining areas undergoing rehabilitation [17] in a subxerophytic area where the ants removed only $5 \%$ of its seeds. Instead, in the same experiment, ants preferred larger arillated seeds such as Capparis sp. (5 $\mathrm{mm}$ in diameter) and Seguieira sp. (4 $\mathrm{mm}$ in diameter). In this experiment, the second most preferred seeds $(P$. dulce) are 60 times heavier than G. ulmifolia seeds, the lightest in this study. This suggests that the context is an important factor in modeling the way ant-seed interactions occur: the presence of other arillated species that compete for the "transporting energy" of foraging ants as well as the presence of key ant species.

Removal occurred with a great degree of activity of key species such as E. ruidum, S. geminata, C. abstinens, and Pheidole spp. during the day while, after 17:00, removal was continued by $C$. major and A. cephalotes. The genera observed transporting seeds in the pasturelands (Table 5) coincide with the functional ant guilds exploiting diaspores in flat, sandy forests, and humid tropical forests in the Brazilian lowlands $[14,42]$. In these habitats, small myrmicines as well as attine actively interacted with diaspores. DominguezHaydar \& Armbrecht [17] identified species of these same functional groups removing seeds. E. ruidum, S. geminate, and Acromyrmex octospinosus were the species that removed the greatest number of seeds from mining lands in early rehabilitation, suggesting that they are key species in the recovery of the ecological function of disturbed areas.

Morphological seed traits, like weight and presence of arils, and foraging strategies in the different ant functional groups are ecologically relevant because they determine how the transport process occur [28]. For example, the foraging of the small-sized myrmicines with generalist habits 
TABle 4: Description of ant species carrying seeds. Body length of workers and its incidence in baits and seed depots (SDs) were recorded, as the seed species they removed. The body length of workers was measured from the posterior margin of clypeus to the posterior end of the last petiole.

\begin{tabular}{|c|c|c|c|c|c|c|}
\hline \multirow{2}{*}{ Ant species } & \multirow{2}{*}{ Workers body length (mm) } & \multicolumn{2}{|c|}{ Presence } & \multicolumn{3}{|c|}{ Seed species removed } \\
\hline & & In baits $\%$ & In SD \% & P. dulce & G. ulmifolia & P. ligularis \\
\hline Atta cephalotes & $12.36 \pm 10.9$ & 1.7 & 1.7 & $\mathrm{X}$ & & \\
\hline Ectatomma ruidum & $5.52 \pm 0.12$ & 36.7 & 35.0 & & $\mathrm{X}$ & $\mathrm{X}$ \\
\hline Solenopsis geminata & $2.12 \pm 0.01$ & 41.7 & 16.7 & & $\mathrm{X}$ & \\
\hline Cyphomyrmex major & $1.85 \pm 0.11$ & 6.7 & 36.7 & & $\mathrm{X}$ & \\
\hline Pheidole susannae & $1.67 \pm 0.01$ & 20.0 & 10.0 & & $\mathrm{X}$ & $\mathrm{X}$ \\
\hline Crematogaster abstinens & $1.58 \pm 0.21$ & 41.7 & 40.8 & $\mathrm{X}$ & & $\mathrm{X}$ \\
\hline
\end{tabular}

TABLE 5: Ant genus classification of ants attracted to baits into the functional groups established by Silvestre et al. [35].

\begin{tabular}{lll}
\hline Item & Functional guild (sensu Silvestre et al. [35]) & Genus attracted to baits \\
\hline$(1)$ & Omnivorous soil dominants & Crematogaster, Pheidole, Solenopsis \\
$(2)$ & Large epigean predators & Ectatomma \\
$(3)$ & Cryptic fungus growers attines & Cyphomyrmex \\
$(4)$ & Leaf-cutter attines & Atta \\
$(5)$ & Agile pseudomyrmecinae & Pseudomyrmex \\
$(6)$ & Soil and vegetation opportunistics & Nylanderia \\
$(7)$ & Small arboreal ants with massive recruitment & Wasmannia \\
$(8)$ & Cryptic ponerinae, specialized predators & Hypoponera \\
\hline
\end{tabular}

is characterized by mass recruiting of workers towards the food resource [35]. The carrying capacity of these ants is limited by their small size, and those seeds that surpass their carrying capacity are foraged on the ground without being displaced [43]. This was observed in the field with species of the Pheidole, Solenopsis, and Wasmannia genera (body length less than $3 \mathrm{~mm}$ ) that foraged the aril of $P$. ligularis and $P$. dulce seeds without removing them. Nevertheless, small myrmicines also team up to transport heavy seeds. In this study, dozens of C. abstinens workers succeeded in moving heavy $P$. dulce seeds from the depots, suggesting that this species is an important functional agent for seed dispersal too.

This study also emphasizes on species of generalist ants considered pests such as S. geminata, E. ruidum, and attines. The tropical fire ant (S. geminata) could be playing a dual role as both predator and seed disperser because, although it is a regular grain collector and eater $[44,45]$, some seeds could survive and germinate in garbage dumps or soils near the nests [29]. On the other hand, E. ruidum has already been identified in Colombia as one of the main seed transporter species in pastures and mining areas under rehabilitation $[16,17,34]$. In Costa Rican agroecosystems, E. ruidum, together with Pheidole fallax, were responsible for $92 \%$ of all observed removal events, E. ruidum being the species that removed most seeds in pastures [15]. The greater size of this ant allows a single worker to carry seeds of different sizes thus increasing the range of seeds that can be dispersed by this species.

Finally, attines such as C. major and A. cephalotes were key transporters of arillated G. ulmifolia and $P$. dulce seeds, respectively. They also acted during evening and nocturnal hours (obs. pers.) thus relaxing competition with other generalist species. These results coincide with the pattern of seed attention described by Rico-Gray \& Oliveira [18] and Bas et al. [46] where attines are usually attracted by nonmyrmecochorous diaspores with large arils and low lipid content $(<8 \%)$. According to the authors, if these diasporas are also light in weight $(<0.1 \mathrm{~g})$, they can be transported greater distances (to $10 \mathrm{~m}$ ), something that could be significant for the lighter G. ulmifolia seeds. The hypothesis of directed dispersion [47-49] can be reinforced when seed removal involves species of attines because the seeds are directed towards the nest where appropriate conditions for germination can be provided. Under conditions of dehydration, aridness, and high temperatures, $A$. cephalotes can concentrate foraging activity at night, and its workers can obtain foraging distances of up to $235 \mathrm{~m}$. Genera of cryptic attine, such as Cyphomyrmex, usually collect seeds during the dry months, and it is when greater foraging distances are reached by its workers [50].

Despite the low removal distances reported for some functional groups, ants can act as complementary dispersing agents [51] bringing up to their nests seeds that have been dispersed long distances (meters, even kilometers) by primary seed dispersers such as cattle, birds, bats, and rodents [52].

In summary, this study presents evidence supporting the idea of ants as functional agents for the ecological recovery of degraded pastures. The preference pattern of the ants for small-sized seeds with attractive structures was confirmed. In spite of the limited diversity of persistent 
ants in the pastures, key species were identified that could provide dispersion service for nonmyrmecochorous species in pastures where barriers to the advance of plant succession exist. The interaction of the different foraging strategies of the participating ants can contribute to the dispersion of seeds through different mechanisms; leaf cutters offer the greatest carrying capacity (quantity and size), and the great majority of seeds will be taken to nests thereby contributing to the reduction of $\mathrm{s}$ competence and depredation by aggregation. Large hunters such as E. ruidum removed seed greater distances and feed on the aril instead of the seed. Antseed interaction was facultative and generalist instead of an obligatory mutualism specific to one species in particular. Far from being an inconvenience, this generalism opens the way to the use of grassland ants as dispersers of plant species ecologically important. This would also be of interest to producers if seed hauling of economically valuable seeds by ants could be induced, for example, through the simulation of artificial arils in those seeds (Henao-Gallego et al. [53]). Ant-seed interaction in grasslands can be taken into account for ecological rehabilitation plans by directing this functional diversity. For the rehabilitation of degraded habitats, these facts could mean that, with an abundant although not very diverse ant biota, rehabilitation actions can be initiated, and the plant species chosen will depend on ant preferences and the ecological context of the pasture to be rehabilitated.

\section{Acknowledgments}

Thanks are due to, Alba Marina Torres, James Montoya, and Zoraida Calle for advice, to Nili Betancur for assisting field work, and to the Ants and GEAHNA Research groups at the Universidad del Valle. To Carlos Moreno for statistical analysis support. Two anonymous reviewers made invaluable suggestions that improved the final version of the manuscript. Thanks are also due to the owners and managers of the farms where the studies were carried out, to the CIPAV Foundation for its institutional support, and to Marcia Dittmann for the English translation. This study was financed by Colciencias through The Project "Las Hormigas como agentes funcionales para la recuperación ecológica de sistemas ganaderos" (Code 110645221048), Basic Sciences Program, and the Universidad del Valle.

\section{References}

[1] E. Murgueitio, C. Cuartas, and J. Naranjo, Ganadería del Futuro: Investigación Para el Desarrollo, Fundación CIPAV, Cali, Colombia, 2008.

[2] P. Chesson, "Mechanisms of maintenance of species diversity," Annual Review of Ecology and Systematics, vol. 31, pp. 343-366, 2000.

[3] T. Tscharntke, C. H. Sekercioglu, T. V. Dietsch, N. S. Sodhi, P. Hoehn, and J. M. Tylianakis, "Landscape constraints on functional diversity of birds and insects in tropical agroecosystems," Ecology, vol. 89, no. 4, pp. 944-951, 2008.

[4] K. D. Holl, "Factors limiting tropical rain forest regeneration in abandoned pasture: seed rain, seed germination, microclimate, and soil," Biotropica, vol. 31, no. 2, pp. 229-242, 1999.
[5] N. C. Nepstad, C. Uhl, C. A. Pereira, and J. M. C. Da Silva, "Comparative study of tree establishment in abandoned pasture and mature forest of eastern Amazonia," Oikos, vol. 76, no. 1, pp. 25-39, 1996.

[6] P. S. Grimbacher and L. Hughes, "Response of ant communities and ant-seed interactions to bush regeneration," Ecological Management and Restoration, vol. 3, no. 3, pp. 188-197, 2002.

[7] P. J. Folgarait, "Ant biodiversity and its relationship to ecosystem functioning: a review," Biodiversity and Conservation, vol. 7, no. 9, pp. 1221-1244, 1998.

[8] S. N. Handel and A. J. Beattie, "Semillas dispersadas por hormigas," Investigación y Ciencia, vol. 263, pp. 76A-83A, 1990.

[9] M. A. Pizo and P. S. Oliveira, "Size and lipid content of nonmyrmecochorous diaspores: effects on the interaction with litter-foraging ants in the Atlantic rain forest of Brazil," Plant Ecology, vol. 157, no. 1, pp. 37-52, 2001.

[10] L. Passos and P. S. Oliveira, "Ants affect the distribution and performance of seedlings of Clusia criuva, a primarily birddispersed rain forest tree," Journal of Ecology, vol. 90, no. 3, pp. 517-528, 2002.

[11] C. C. Horvitz and A. J. Beattie, "Ant dispersal of Calathea (Marantaceae) seeds by carnivorous Ponerines (Formicidae) in a tropical rain-forest," American Journal of Botany, vol. 67, pp. 321-326, 1980.

[12] C. C. Horvitz and D. W. Schemske, "Seed dispersal of a neotropical myrmecochore: variation in removal rates and dispersal distance," Biotropica, vol. 18, pp. 319-323, 1986.

[13] J. W. Dalling and R. Wirth, "Dispersal of Miconia argentea seeds by the leaf-cutting ant Atta Colombica," Journal of Tropical Ecology, vol. 14, no. 5, pp. 705-710, 1998.

[14] M. A. Pizo and P. S. Oliveira, "The use of fruits and seeds by ants in the Atlantic forest of Southeast Brazil," Biotropica, vol. 32, no. 4b, pp. 851-861, 2000.

[15] T. J. Zelikova and M. D. Breed, "Effects of habitat disturbance on ant community composition and seed dispersal by ants in a tropical dry forest in Costa Rica," Journal of Tropical Ecology, vol. 24, no. 3, pp. 309-316, 2008.

[16] S. Escobar, I. Armbrecht, and Z. Calle, "Transporte de semillas por hormigas en bosques y agroecosistemas ganaderos de los Andes Colombianos," Agroecología, vol. 2, pp. 65-74, 2007.

[17] Y. Dominguez-Haydar and I. Armbrecht, "Response of ants and their seed removal in rehabilitation areas and forests at El Cerrejón Coal Mine in Colombia," Restoration Ecology, vol. 19, no. 201, pp. 178-184, 2011.

[18] V. Rico-Gray and P. S. Oliveira, The Ecology and Evolution of Ant-Plant Interactions, University of Chicago Press, Chicago, Ill, USA, 2007.

[19] M. A. Pizo and P. S. Oliveira, "Interaction between ants and seeds of a nonmyrmecochorous neotropical tree, Cabralea canjerana (Meliaceae), in the Atlantic forest of southeast Brazil," American Journal of Botany, vol. 85, no. 5, pp. 669-674, 1998.

[20] P. Dostál, M. Březnová, V. Kozlíčková, T. Herben, and P. Kovář, "Ant-induced soil modification and its effect on plant belowground biomass," Pedobiologia, vol. 49, no. 2, pp. 127-137, 2005.

[21] A. G. Farji Brener and J. F. Silva, "Leaf-cutter ants' (Atta laevigata) aid to the establishment success of Tapirira velutinifolia (Anacardiaceae) seedlings in a parkland savanna," Journal of Tropical Ecology, vol. 12, no. 1, pp. 163-168, 1996.

[22] B. Lafleur, L. M. Hooper-Bùi, E. P. Mumma, and J. P. Geaghan, "Soil fertility and plant growth in soils from pine forests and plantations: effect of invasive red imported fire ants Solenopsis 
invicta (Buren)," Pedobiologia, vol. 49, no. 5, pp. 415-423, 2005.

[23] J. Retana, F. X. Picó, and R. Anselm, "Dual role of harvesting ants as seed predators and dispersers of a non-myrmechorous Mediterranean perennial herb," Oikos, vol. 105, no. 2, pp. 377385, 2004.

[24] C. Gómez and X. Espadaler, "Falling or movement of seeds and the presence of an elaiosome: its effect on ant reaction (Hymenoptera: Formicidae) in a myrmecochorous species, Euphorbia characias (Euphorbiaceae)," Sociobiology, vol. 30, no. 2, pp. 175-183, 1997.

[25] L. Hughes and M. Westoby, "Effect of diaspore characteristics on removal of seeds adapted for dispersal by ants," Ecology, vol. 73, no. 4, pp. 1300-1312, 1992.

[26] S. N. Gorb and E. V. Gorb, "Removal rates of seeds of five myrmecochorous plants by the ant Formica polyctena (Hymenoptera: Formicidae)," Oikos, vol. 73, no. 3, pp. 367374, 1995.

[27] C. Gómez and X. Espadaler, "Myrmecochorous dispersal distances: a world survey," Journal of Biogeography, vol. 25, no. 3, pp. 573-580, 1998.

[28] J. H. Ness, J. L. Bronstein, A. N. Andersen, and J. N. Holland, "Ant body size predicts dispersal distance of ant-adapted seeds: implications of small-ant invasions," Ecology, vol. 85, no. 5, pp. 1244-1250, 2004.

[29] D. J. Levey and M. M. Byrne, "Complex ant-plant interactions: rain forest ants as secondary dispersers and post-dispersal seed predators," Ecology, vol. 74, no. 6, pp. 1802-1812, 1993.

[30] L. S. Espinal, Zonas de vida de Colombia, Universidad Nacional de Colombia, Facultad de Ciencias, Departamento de Ciencias de la Tierra, Medellín, Colombia, 1990.

[31] A. Perafán, "Transformaciones paisajísticas en la zona plana vallecaucana," Historia y Espacio Revista del Departamento de Historia Universidad del Valle, vol. 24, pp. 1-18, 2005.

[32] A. Jaramillo-Robledo and B. Chaves-Córdoba, "Distribución de la precipitación en Colombia analizada mediante conglomeración estadística," Cenicafé, vol. 51, no. 2, pp. 102-113, 2000.

[33] Royal Botanic Gardens Kew, "Seed information database (SID). Version 7.1," May 2008, http://data.kew.org/sid/ .

[34] C. Santamaría, I. Armbrecht, and J. P. Lachaud, "Nest distribution and food preferences of Ectatomma ruidum (Hymenoptera: Formicidae) in shaded and open cattle pastures of Colombia," Sociobiology, vol. 53, no. 2, pp. 517-541, 2009.

[35] R. Silvestre, C. R. F. Brandão, and R. Rosa da Silva, "Grupos funcionales de hormigas: el caso de los gremios del Cerrado," in Introducción a Las Hormigas de La Región Neotropical, F. Fernández, Ed., pp. 113-148, Instituto de Investigación de Recursos Biológicos Alexander von Humboldt, Bogotá, Colombia, 2003.

[36] J. A. Ludwig and J. F. Reynolds, Statistical Ecology: A Primer of Methods and Computing, John Wiley \& Sons, New York, NY, USA, 1988.

[37] SAS Institute Inc., "SAS 9.1.3 Help and Documentation," Cary, NC: SAS Institute Inc., 2002-2004.

[38] M. Ramírez, I. Armbrecht, and M. L. Enríquez, "Importancia del manejo agrícola para la biodiversidad: caso de las hormigas en la caña de azúcar," Revista Colombiana de Entomología, vol. 30, no. 1, pp. 115-123, 2004.

[39] A. Arcila, Afecta la fragmentación la colonización de especies oportunistas?, Ph.D. thesis, Universidad del Valle, Biology Department, Cali, Colombia, 2007.

[40] R. Achury, P. Ulloa-Chacón, and A. M. Arcila, "Composición de hormigas e interacciones competitivas con Wasmannia auropunctata en fragmentos de bosque seco tropical," Revista Colombiana de Entomología, vol. 34, no. 2, pp. 209-216, 2008.

[41] I. Armbrecht and P. Ulloa-Chacón, "Rarity and diversity of ants in dry forest fragments and its matrices in Colombia," Biotropica, vol. 31, no. 4, pp. 646-653, 1999.

[42] L. Passos and P. S. Oliveira, "Interactions between ants, fruits and seeds in a restinga forest in south-eastern Brazil," Journal of Tropical Ecology, vol. 19, no. 3, pp. 261-270, 2003.

[43] C. R. Carroll and D. H. Janzen, "Ecology of foraging by ants," Annual Review of Ecology and Systematics, vol. 4, pp. 231-257, 1973.

[44] I. Perfecto, "Dynamics of Solenopsis geminata in a tropical fallow field after ploughing," Oikos, vol. 62, no. 2, pp. 139-144, 1991.

[45] C. R. Carroll and S. J. Risch, "The dynamics of seed harvesting in early successional communities by a tropical ant, Solenopsis geminata," Oecologia, vol. 61, no. 3, pp. 388-392, 1984.

[46] J. M. Bas, J. Oliveras, and C. Gómez, "Myrmecochory and short-term seed fate in Rhamnus alaternus: ant species and seed characteristics," Acta Oecologica, vol. 35, no. 3, pp. 380$384,2009$.

[47] F. Howe and J. Smallwood, "Ecology of seed dispersal," Annual Review of Ecology and Systematics, vol. 13, pp. 201-228, 1982.

[48] D. G. Wenny, "Advantages of seed dispersal: a re-evaluation of directed dispersal," Evolutionary Ecology Research, vol. 3, no. 1, pp. 51-74, 2001.

[49] I. Giladi, "Choosing benefits or partners: a review of the evidence for the evolution of myrmecochory," Oikos, vol. 112, no. 3, pp. 481-492, 2006.

[50] I. R. Leal and P. S. Oliveira, "Foraging ecology of attine ants in a Neotropical savanna: seasonal use of fungal substrate in the cerrado vegetation of Brazil," Insectes Sociaux, vol. 47, no. 4, pp. 376-382, 2000.

[51] S. B. Vander Wall and W. S. Longland, "Diplochory: are two seed dispersers better than one?" Trends in Ecology and Evolution, vol. 19, no. 3, pp. 155-161, 2004.

[52] A. V. Christianini and P. S. Oliveira, "Birds and ants provide complementary seed dispersal in a neotropical savanna," Journal of Ecology, vol. 98, no. 3, pp. 573-582, 2010.

[53] N. Henao-Gallego, S. Escobar-Ramírez, Z. Calle, J. MontoyaLerma, and I. Armbrecht, "An artificial aril designed to induce seed hauling by ants for ecological rehabilitation purposes," Restoration Ecology. In press. 

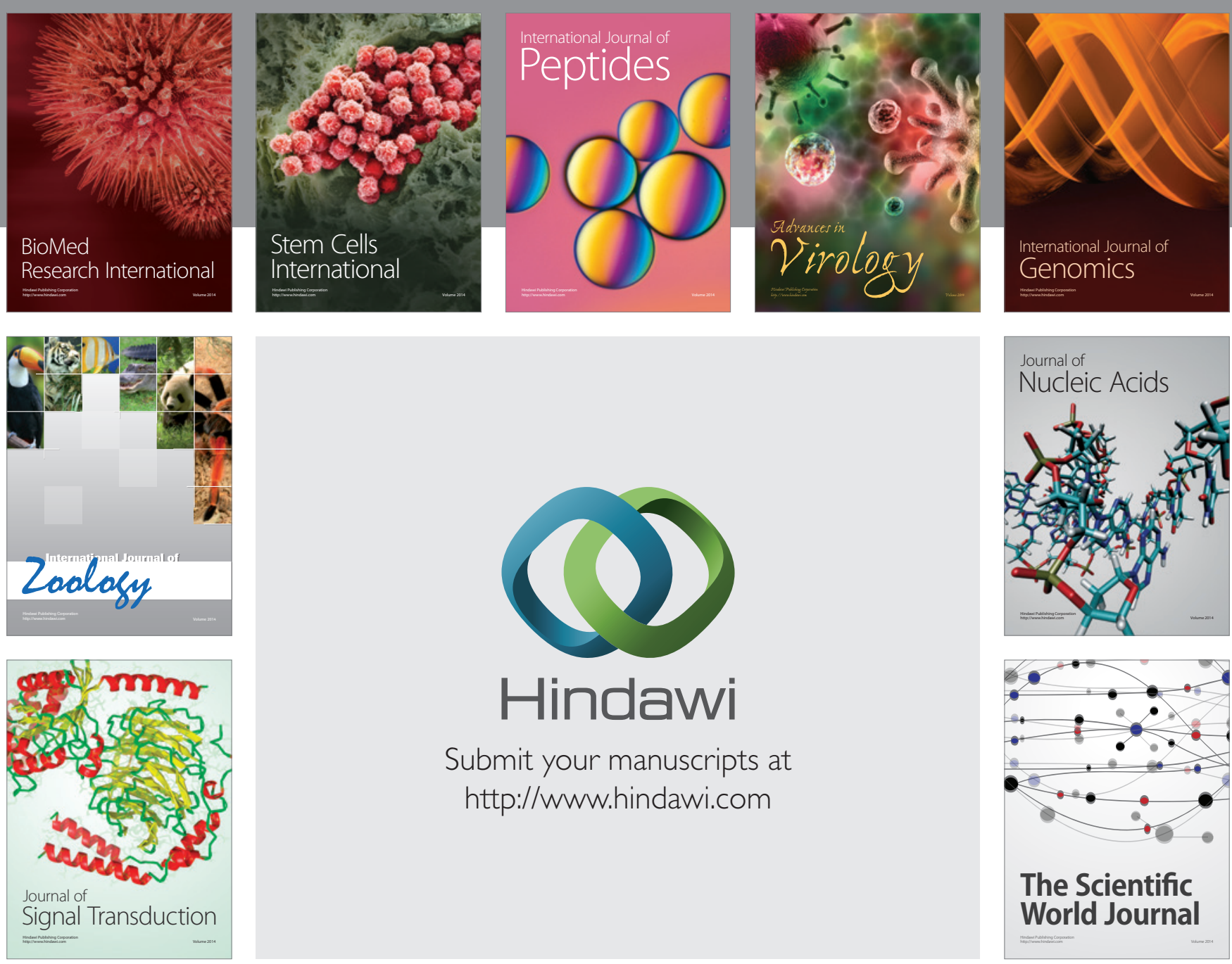

Submit your manuscripts at

http://www.hindawi.com
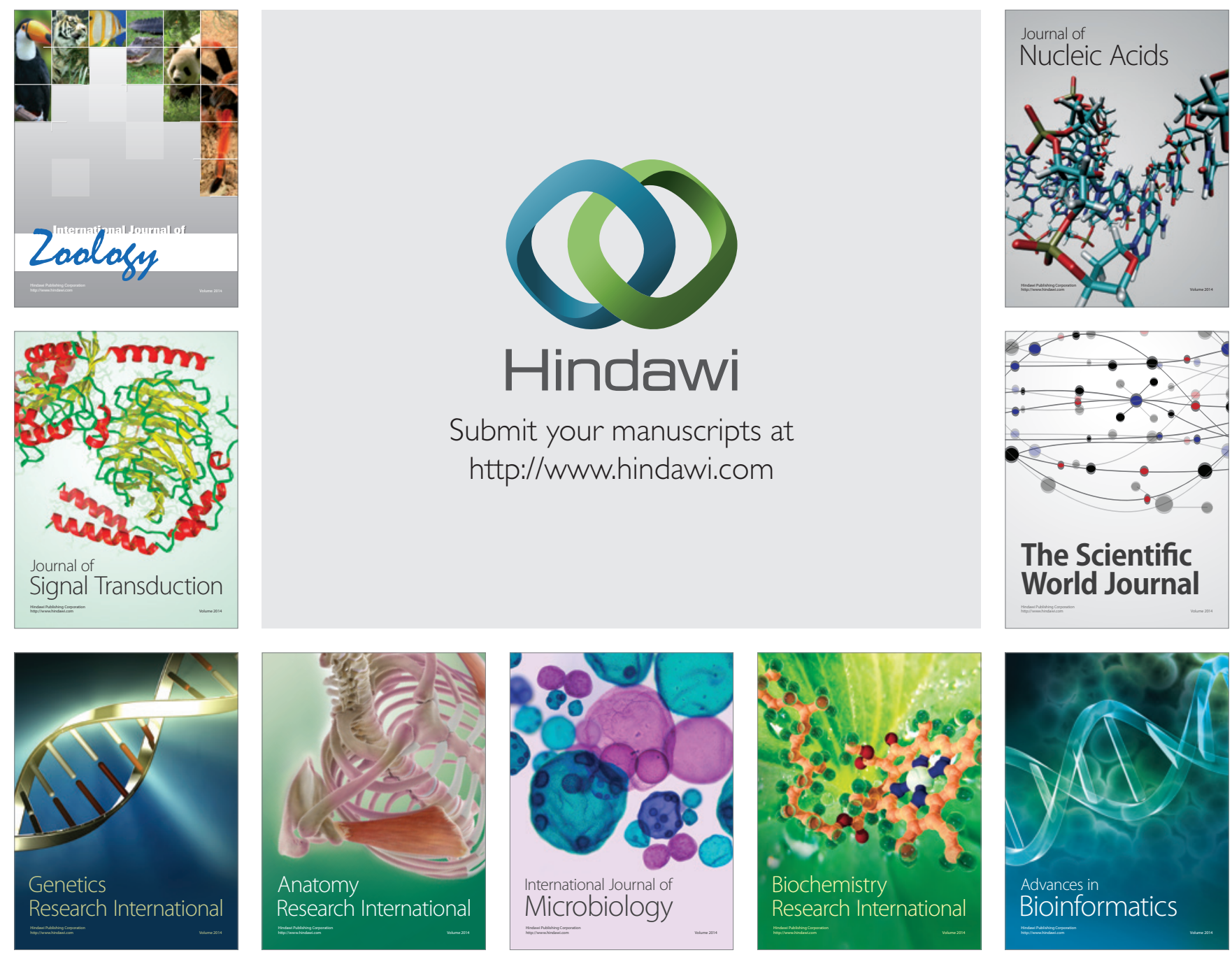

The Scientific World Journal
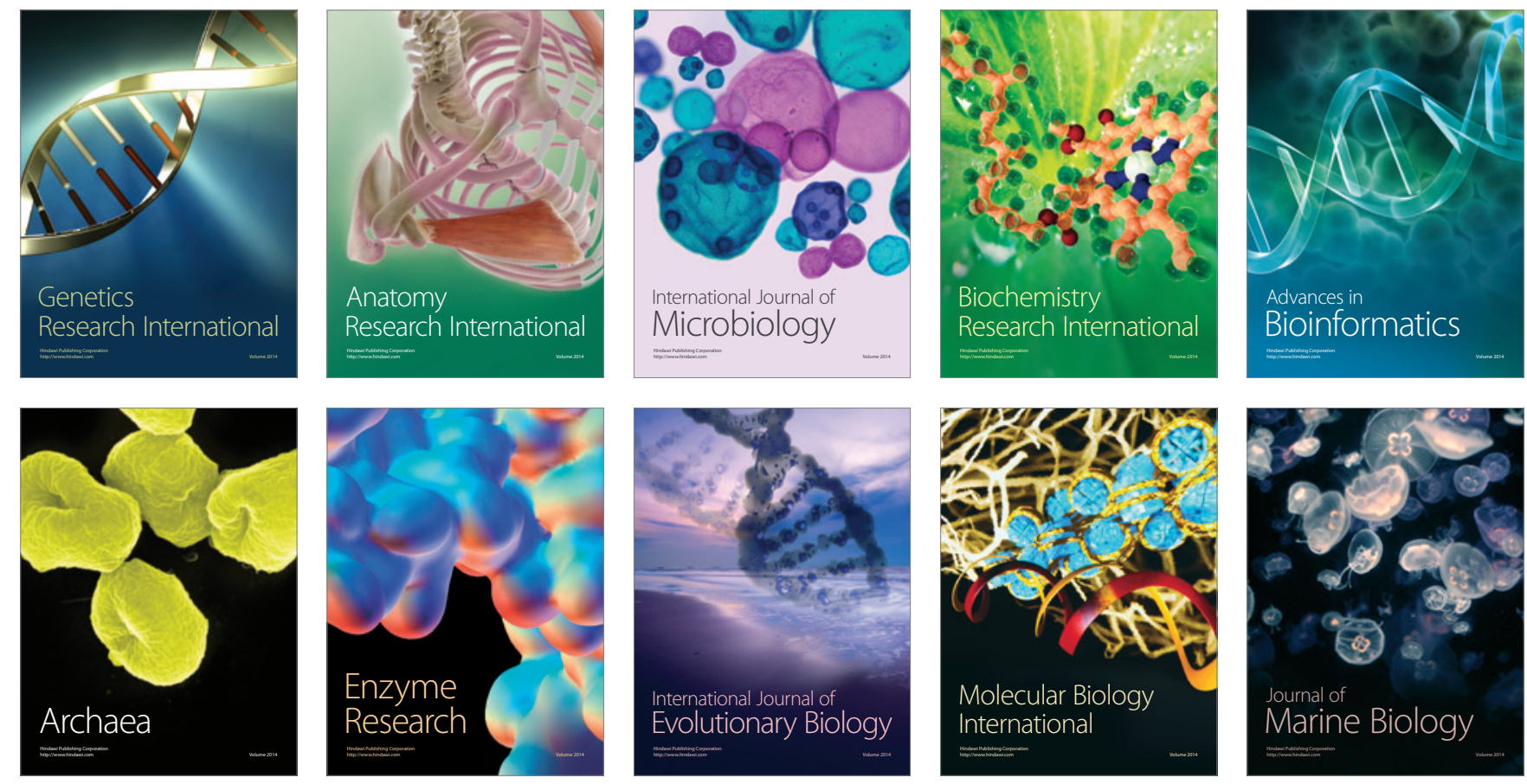